\title{
Structural evolution of JG and JD fields, Abu Gharadig basin, Western Desert, Egypt, and its impact on hydrocarbon exploration
}

\author{
Hamdy Mahmoud ${ }^{1}$ D Hamza Lotfy ${ }^{2} \cdot$ Ali Bakr²,3
}

Received: 23 October 2018 / Accepted: 20 July 2019 / Published online: 31 July 2019

(c) The Author(s) 2019

\begin{abstract}
The Abu Gharadig basin in the Western Desert (NW Egypt) is a mature hydrocarbon province with over 95\% of the oil and gas fields in the Upper Cretaceous reservoirs. JG and JD fields are producing fields; JG is producing from the Jurassic reservoirs, while the JD field is producing from the shallower Tertiary reservoir. Both fields lie on the footwall of the main bounding fault of Abu Gharadig basin trending E-W and NW-SE. Four dry wells have been drilled into the deeper Jurassic reservoir, and this paper will try to figure out the possible reasons for the failure of Jurassic reservoir in JD compared to JG field 2002. Two main geological cross sections have been created. The first cross section ties the JD field to the Abu Gharadig basin and the second one ties the JG field to same depocenter. The restoration has been carried out using 2D Move (Midland Valley software) to restore the two sections to their original tectonic status. Since the Eocene-Miocene is the common time for the hydrocarbon expulsion in Abu Gharadig basin, both JG and JD traps were formed at that time. The restoration clearly showed the juxtaposition of the Jurassic reservoirs against Abu Roash and Khoman (shale, limestone and chalk) in JG. In contrary, the Jurassic reservoir is juxtaposed with Kharita and Alam El Bueb (Sandstone) in JD. Fault juxtaposition has been carried out also and concluded the juxtaposition of Abu Roash F member and Masajid flip East of JD well so no chance of Abu Roash F member charging JD.
\end{abstract}

Keywords Structural evolution $\cdot$ Hydrocarbon exploration $\cdot$ JG field $\cdot$ JD field $\cdot$ Western desert

\section{Introduction}

The Abu Gharadig basin in the Western Desert (NW Egypt) is a mature hydrocarbon province with over $95 \%$ of the oil and gas fields in the Upper Cretaceous Abu Roash, Bahariya and Kharita sandstone reservoirs. Many wells had penetrated the thick Lower Cretaceous Alam El Bueib sandstone reservoir, but no significant discoveries were made. This led most operators to believe that there was very little prospectivity at deeper levels, in particular in the Jurassic Safa sandstones overlying the Paleozoic basement. JG filed is one of the main oil-producing fields from the Jurassic section in Abu Gharadig basin and JD is the closest one for it; both of them are on the main bounding fault for Abu Gharadig basin, but JD

Hamdy Mahmoud

h.mahmoud4@bapetco.net; hamdy.ahmed2010@gmail.com

Badr Petroleum Company (BAPETCO), Cairo, Egypt

2 Al Minya University, Al Minya, Egypt

3 Geoconsultant, Cairo, Egypt wells were dry. This study will answer this mystery. The structure of the JG field is an elongated E-W fault dip closure bounded to the south by the Cretaceous Abu Gharadig basin-bounding fault. It is bisected by a series of smaller ENE-WSW and NW-SE trending. The JD structure consists of an elongated NE-SW-trending fault/dip closure mapped at the Jurassic Masajid level. To the SW, the JD closure is bounded by the Abu Gharadig basin-bounding faults. This fault system consists of fault throw transfers, a complex of relay ramps and hard fault linkages all in an area with poor seismic data quality. Toward the SE, the main AG fault terminates and the main part of the fault throw is transferred to the southern fault and a relay ramp is developed in between the two faults which are well developed at the Base Khoman level in the basin. Another fault is developed $\mathrm{E}$ of the main AG fault, and this fault also takes over part of the throw of the main AG fault. This fault is linked to the main AG fault by a relay ramp at Alamein level and by a hard-linked fault at the Masajid level. The main purpose of this paper is to evaluate and compare the reservoir intervals of JG and JD fields to investigate the structural evolution and its impact 
on the petroleum potentiality of the fields. The seismic interpretation and the $2 \mathrm{D}$ restoration are the main workflow items to figure out why JD is dry at the Jurassic level and JG is producing from the same level while they are very close to each other and lies on the same main bounding fault.

\section{Location of study area}

The study area is located in the northern part of the Western Desert in Abu Gharadig basin. It is delineated by latitudes $29^{\circ} \mathrm{N}$ and $30^{\circ} \mathrm{N}$ and longitudes $27^{\circ} 53^{\prime} \mathrm{E}$ and $30^{\circ} 7^{\prime} \mathrm{E}$ (Fig. 1).

The Abu Gharadig basin (Fig. 1) is an E-W-oriented asymmetric graben and represents one of the most important productive basins in the northern part of the Western Desert. It extends for about $300 \mathrm{~km}$ in length and $60 \mathrm{~km}$ in width. The sedimentary cover of this basin ranges in age from Late Jurassic to Miocene. The Sharib-Sheiba high constitutes the northern border of the basin; the Sitra platform is its southern limit; the Kattaniya-Abu Roash high lies to its east and Faghur-Siwa basin to its west (Abdelmalek and Zeidan 1994). The Sitra field contains a series of right-stepping en-echelon faults that strike WNW-ESE, defining a series of WNW-ESE Geologic Setting (Figs. 2, 3).

\section{Structural phases in Abu Gharadig basin}

The Abu Gharadig basin area is primarily extensional in nature and is affected mainly by faulting, and folding is relatively subordinate and is often related to movements on nearby faults. Three different types of faults are recognized by seismic in the area. These are normal, reverse and strike-slip (right and left lateral) faults. Normal faults are the most predominant of these types, while strike-slip faults are the least in number. The sense of lateral slip on strike slip faults can often be determined by matching offset structures on both sides of fault. The normal faults (771 faults) affecting the Abu Gharadig basin area trend in three main directions. These are oriented ENE, E-W, and WNW R (Guiraud and Bosworth 1997). The maximum amount of throw on the major normal faults in the basin is up to $2450 \mathrm{~m}$. Reverse faults in the study area are fewer in number than the normal faults; only 23 reverse faults were recognized and mapped. These are oriented in two main directions that trend ENE

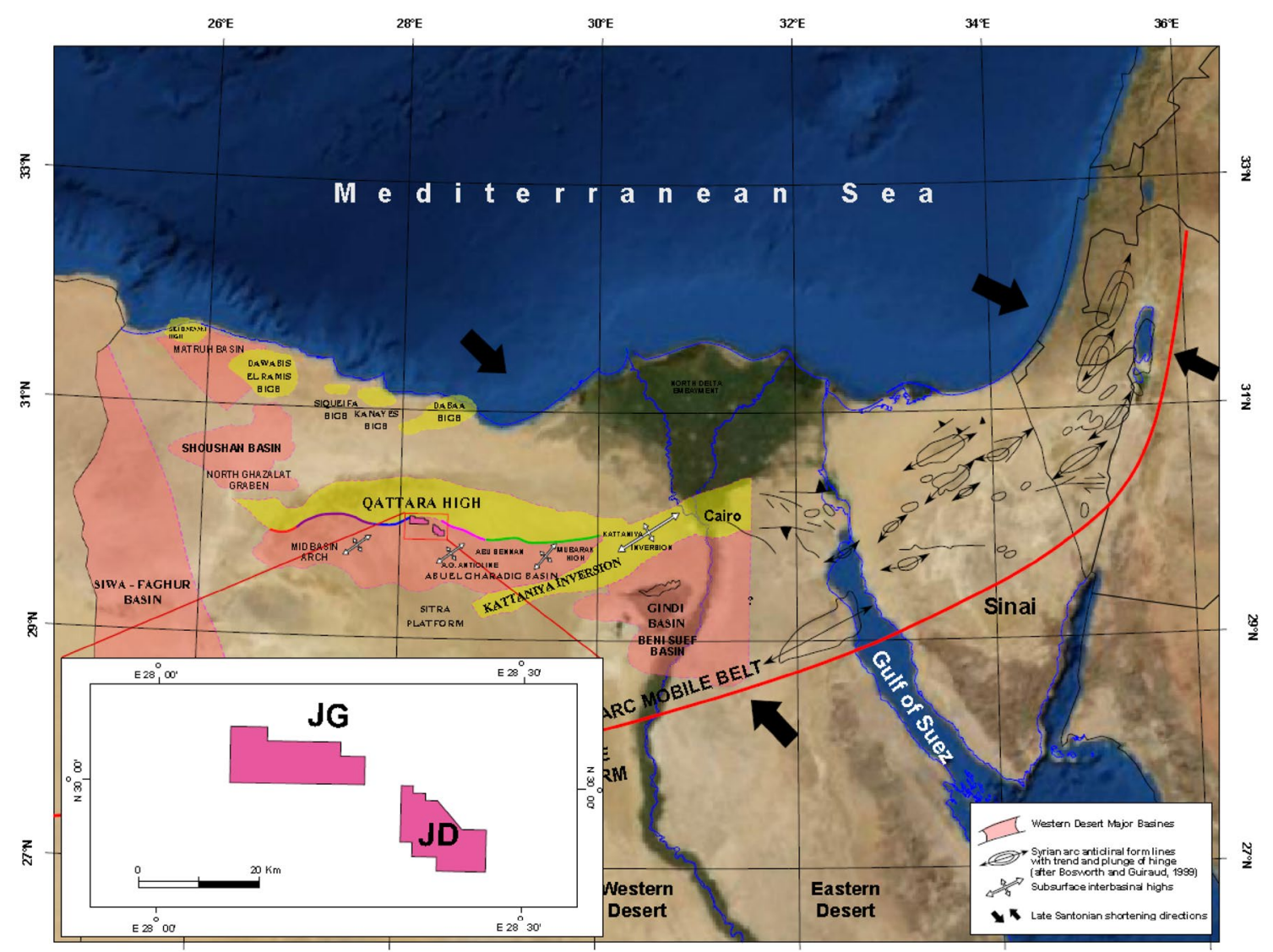

Fig. 1 Location map of the study area showing JG and JD fields 


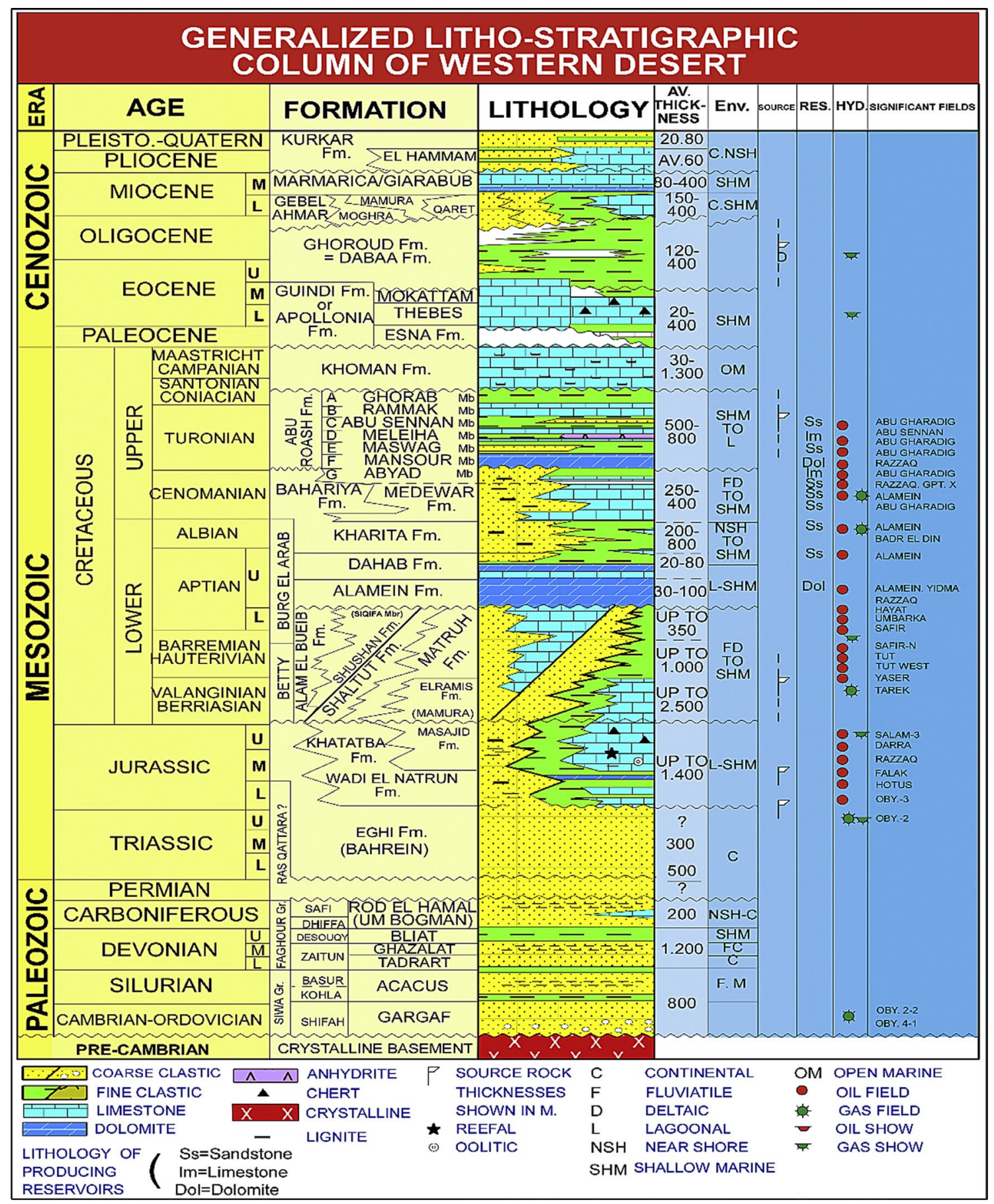

Fig. 2 Generalized lithostratigraphic column of the northwestern desert of Egypt (Schlumberger 1984, 1995)

and E-W. Right- and left-lateral strike-slip faults in the study area are very few in numbers. While a clear preferred orientation for these faults is not clear, there does appear to be a NNE to a NE with a secondary NE direction present. Most of the faults affecting the Abu Gharadig basin die out in the Senonian Khoman Formation. This indicates that the major tectonic movements which gave the Abu Gharadig basin its present shape took place near the end of the Late Cretaceous. Rejuvenation of some faults took place during the Eocene. The basin has an irregular rhomb shape and includes at least three sub-basins of a similar shape and predominantly controlled by ENE- to E-W-oriented faults which parallel their long axes (Fig. 4). The faulting was initiated during the Early Jurassic and forms a pervasive grain 


\section{Structural phases in AG Basin}
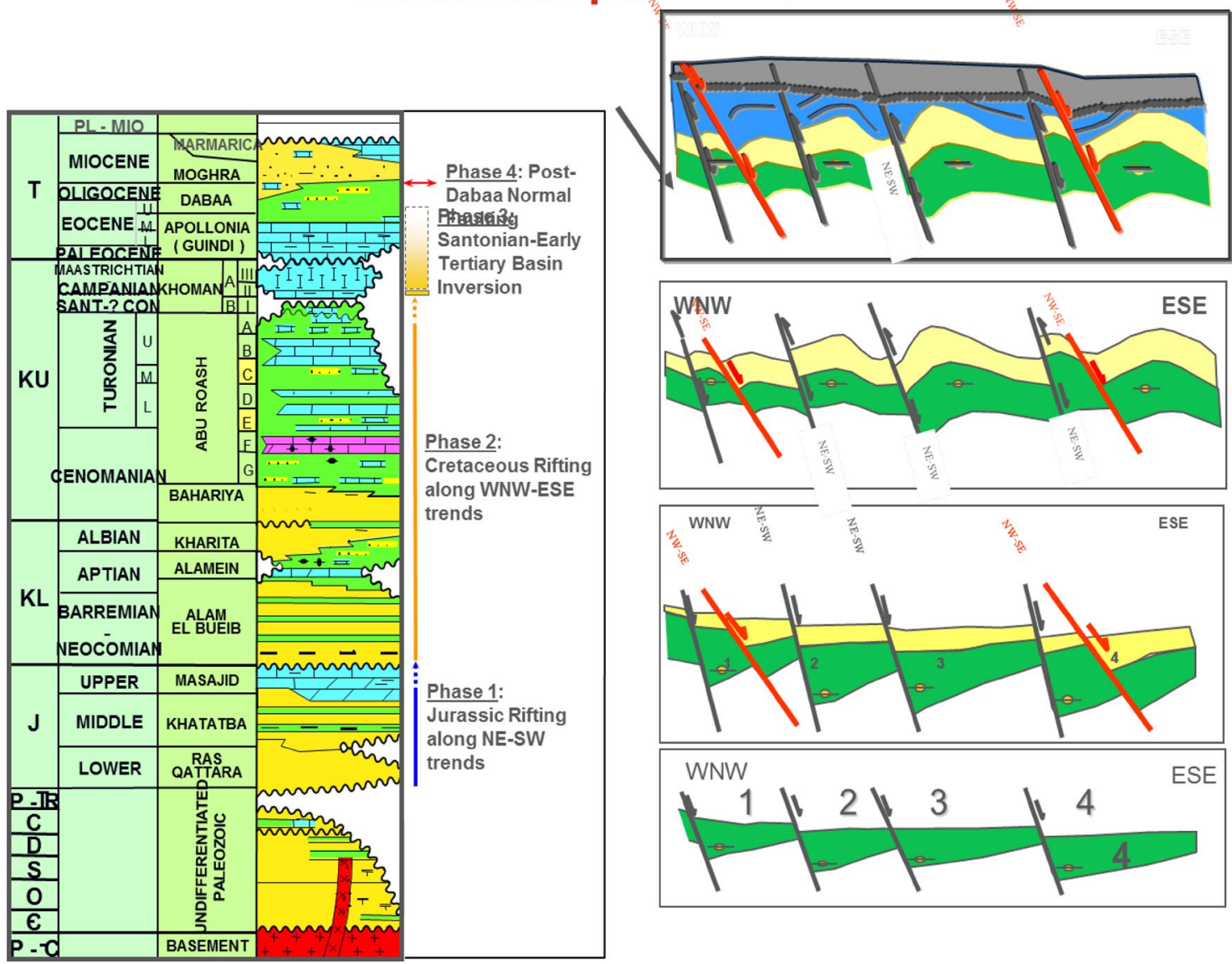

WNW ESE

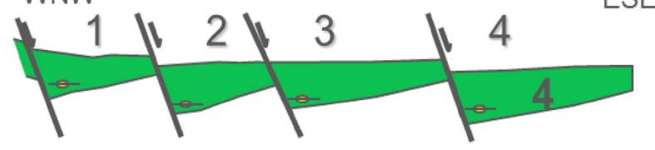

Fig. 3 Structural setting of Abu Gharadig basin (internal study in BAPETCO)

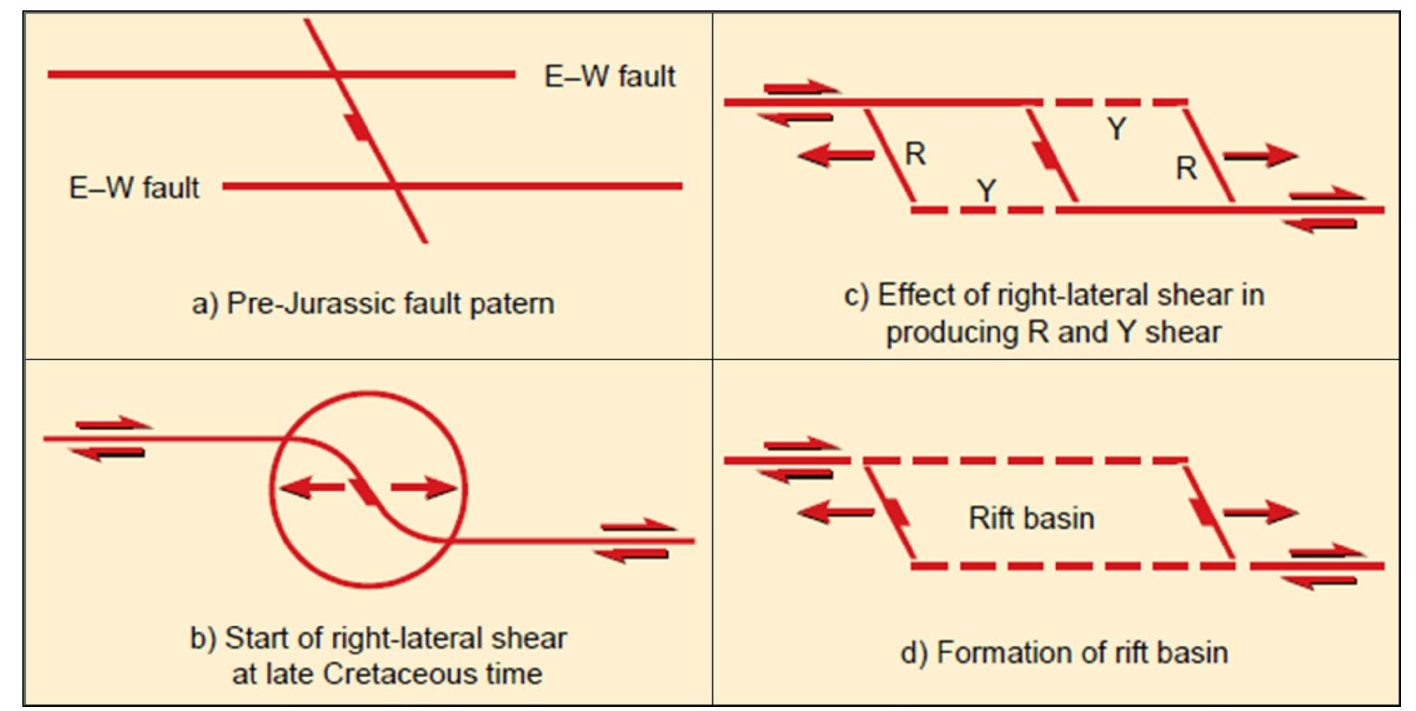

Fig. 4 Proposed model for Abu Gharadig basin [modified after Meshref et al. (1988)] 


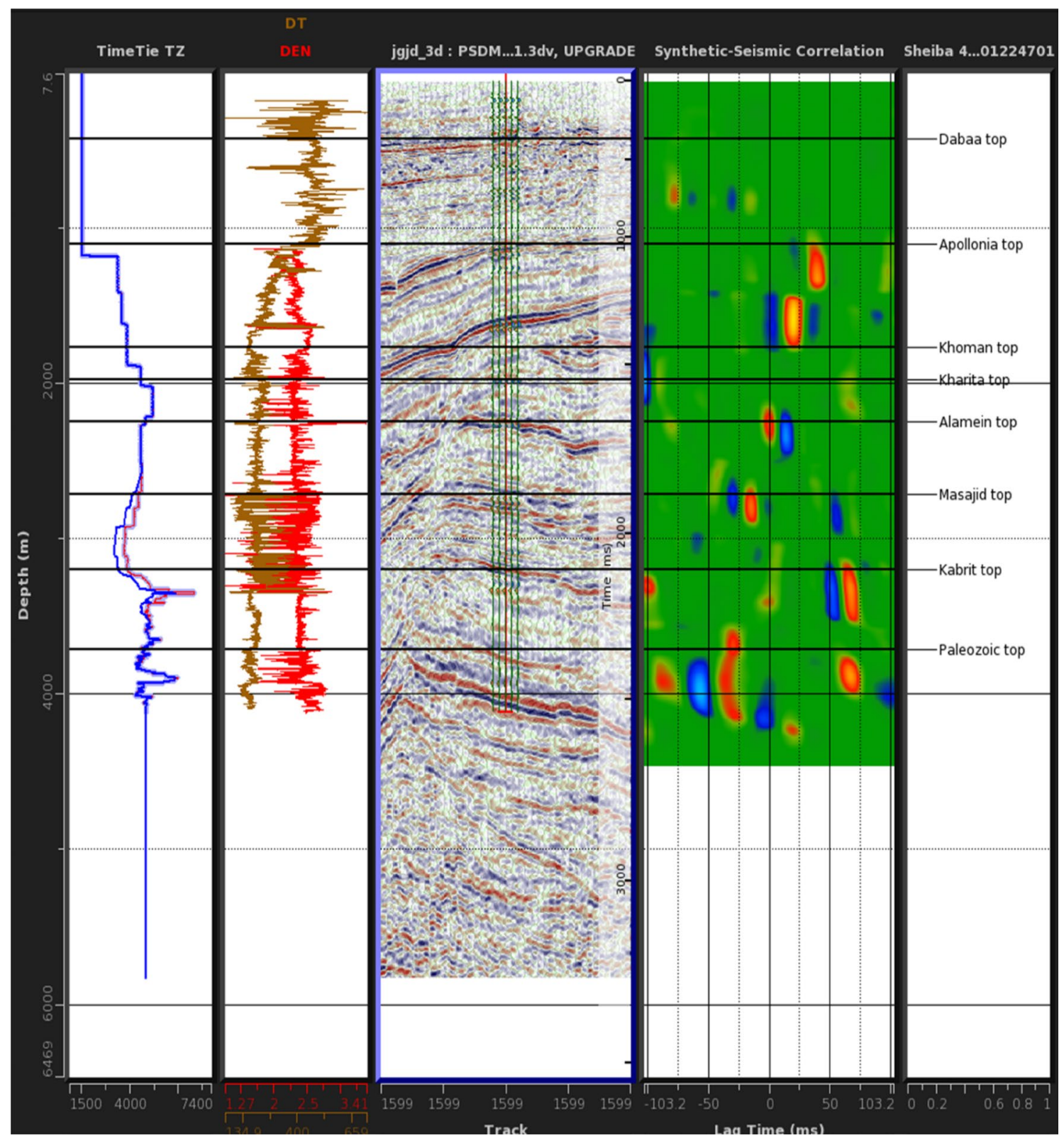

Fig. 5 Synthetic seismograms for Sheiba 42-1 well in JG block showing the good tie between the seismic and the well tops till to PZ section

in northern Egypt. The faults most probably originated as extensional features during the opening of the Tethys that accompanied the breakup of North Africa from Eurasia in the Late Triassic-Early Jurassic (Biju-Duval et al. 1979). They could have existed, however, as zones of weakness in the basement Precambrian Schürmann (1974) and Orwig (1982) and rejuvenated as normal faults during the opening of the Tethys. According to Lotfy (1989), the Initiation of the Abu Gharadig basin started during the Late Jurassic as a result of the intrusion of a deep-seated basaltic and dolerite mantle bulge, related to the early phase of the Alpine orogeny.

According to Smith (1971), Africa moved eastward relative to Eurasia in the Early Jurassic and westward during the Late Cretaceous. The westward movement of Africa most probably caused rejuvenation of the ENE- to E-W-oriented 


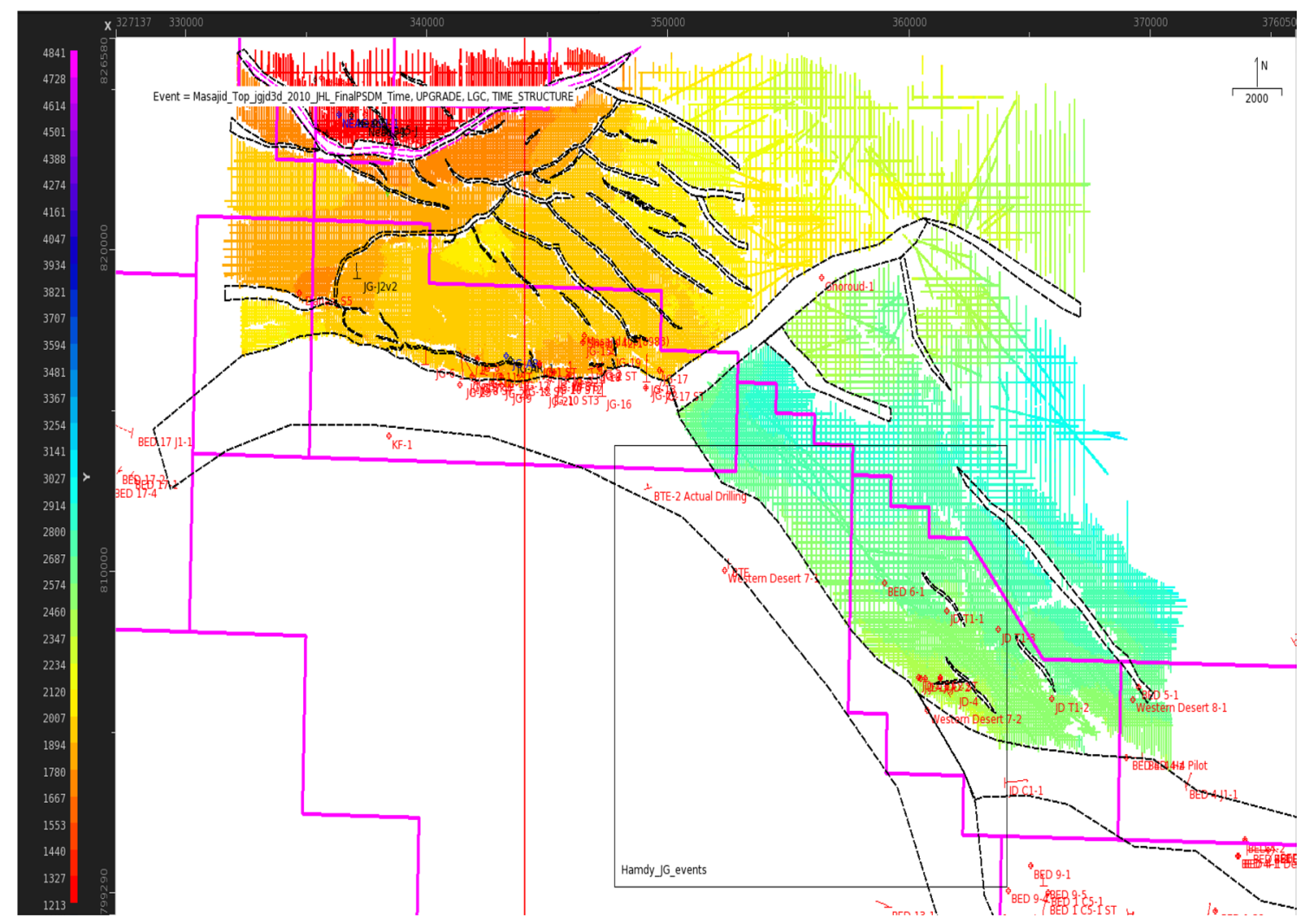

Fig. 6 Masajid seeds (interpretation) over JG and JD areas

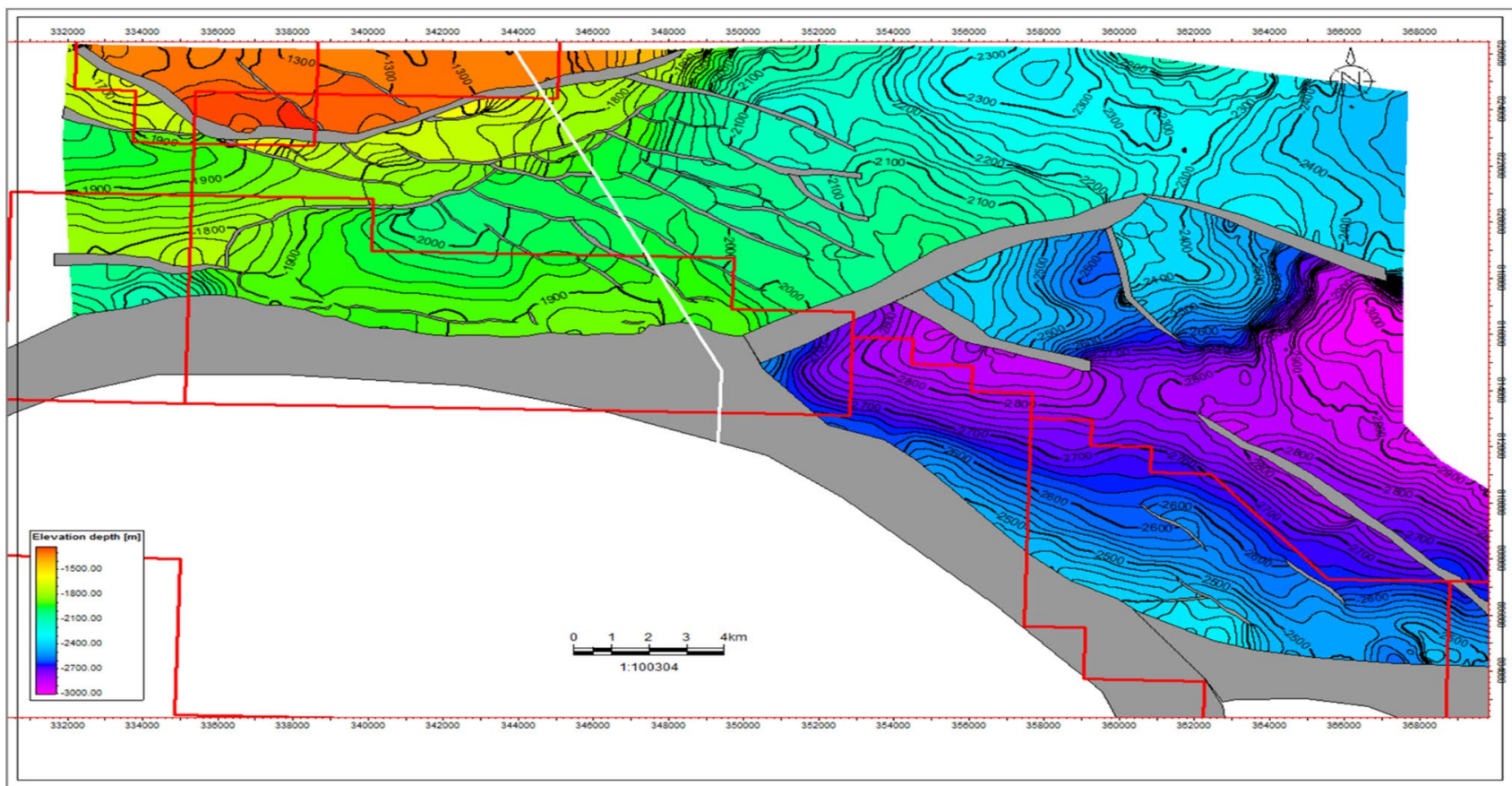

Fig. 7 Masajid structure contour map 


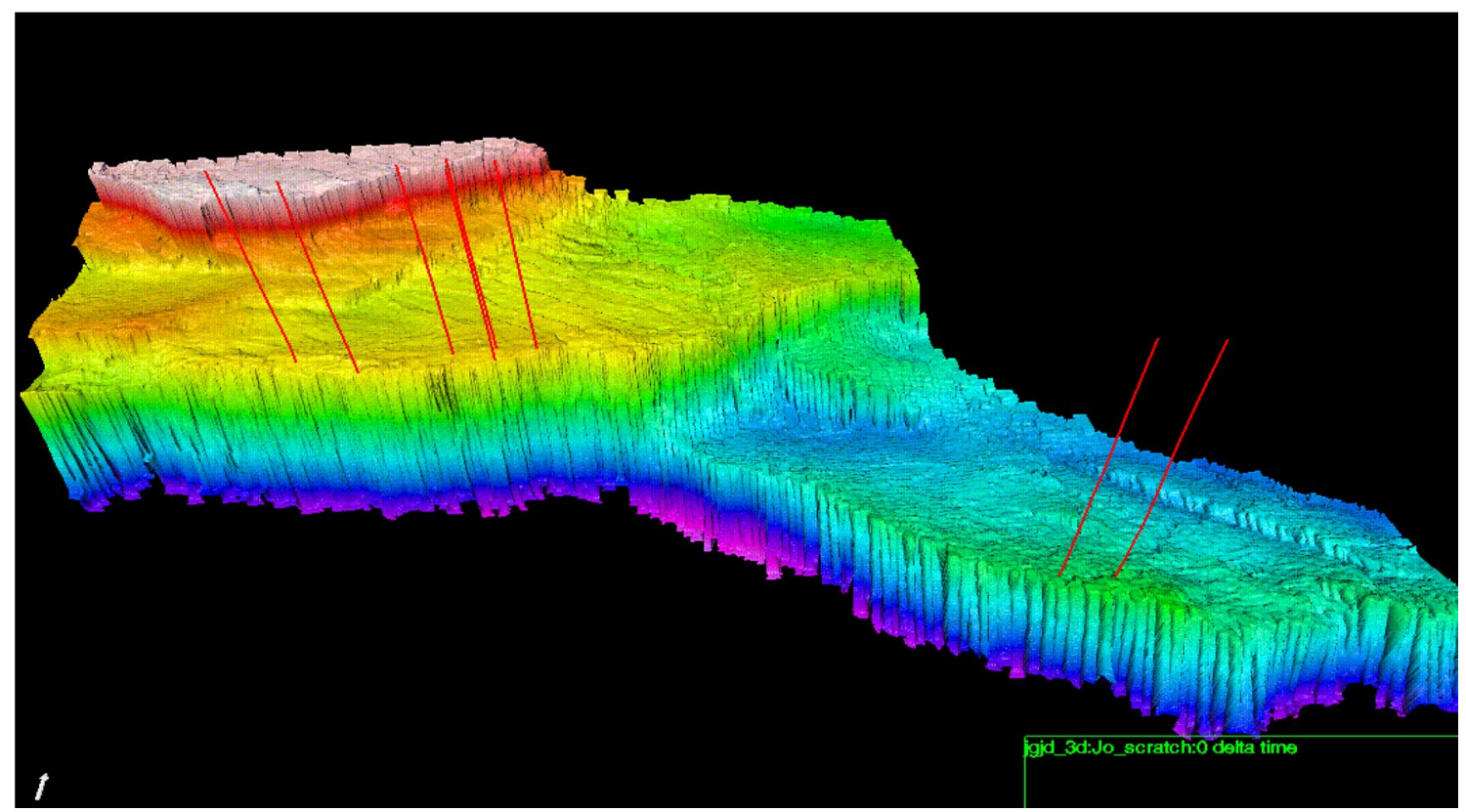

Fig. 8 3D view for top Masajid over JG and JD fields

NW-SE seismic line in footwall connecting JG field to JD area

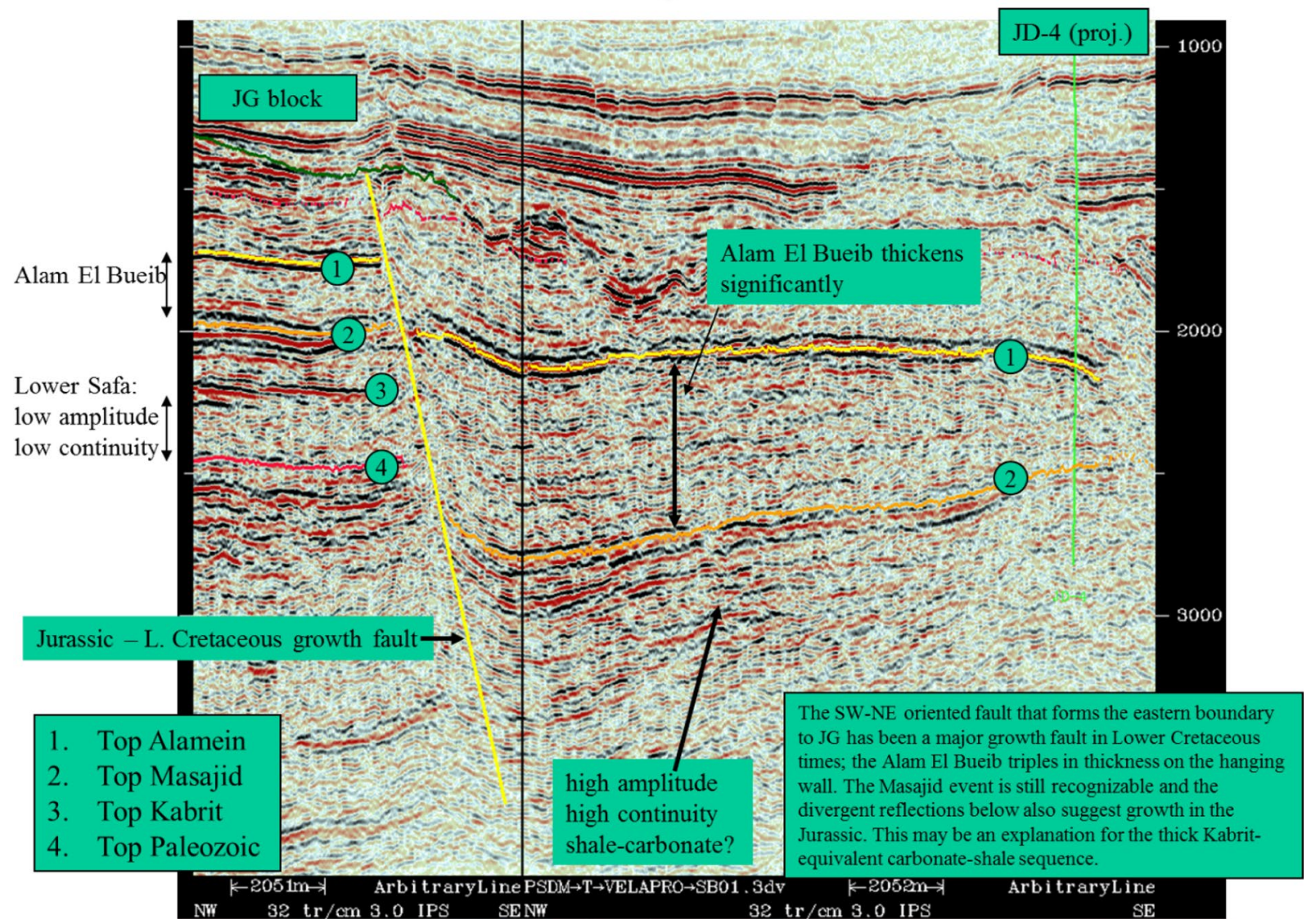

Fig. 9 NW-SE (A-B) seismic line in footwall connecting JG and JD 


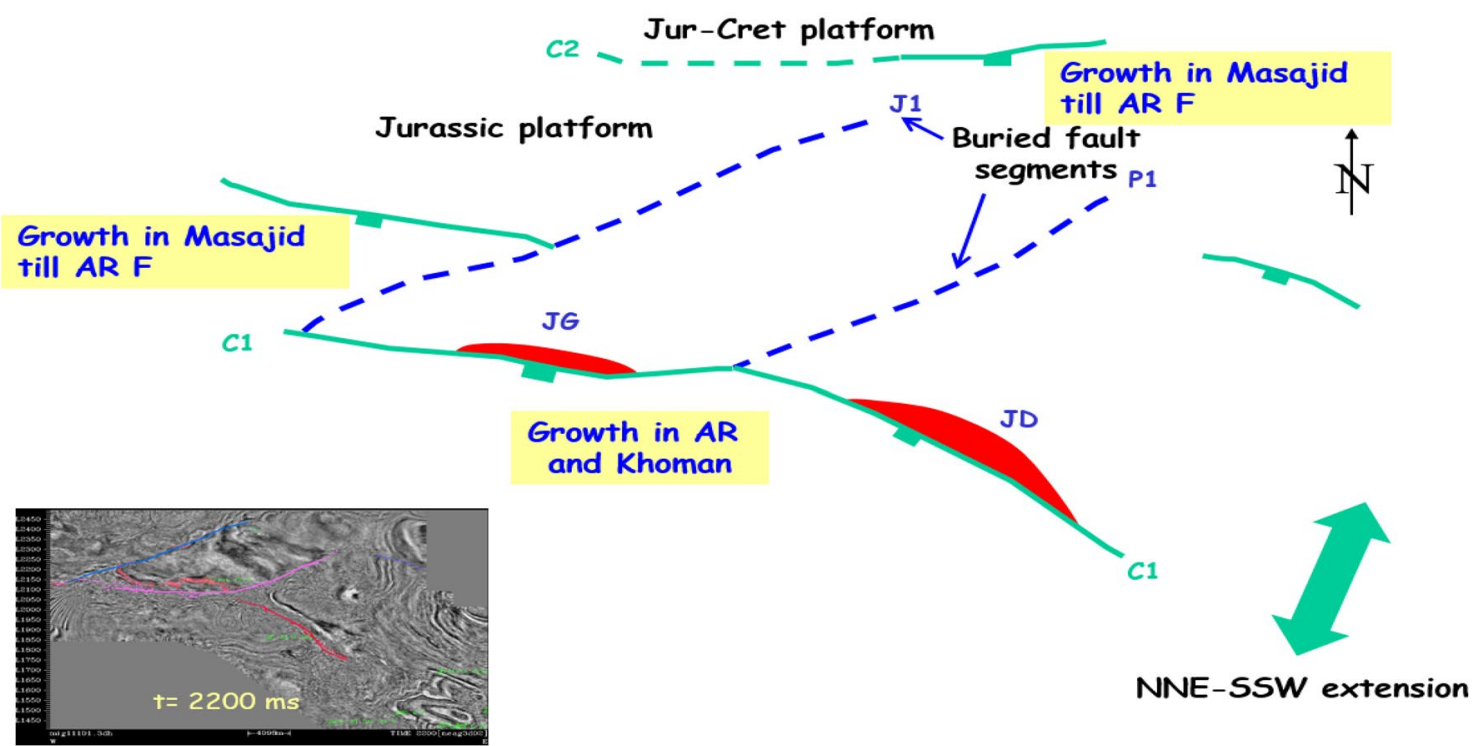

Fig. 10 Schematic map showing the Cretaceous and Jurassic fault system over JG and JD fields

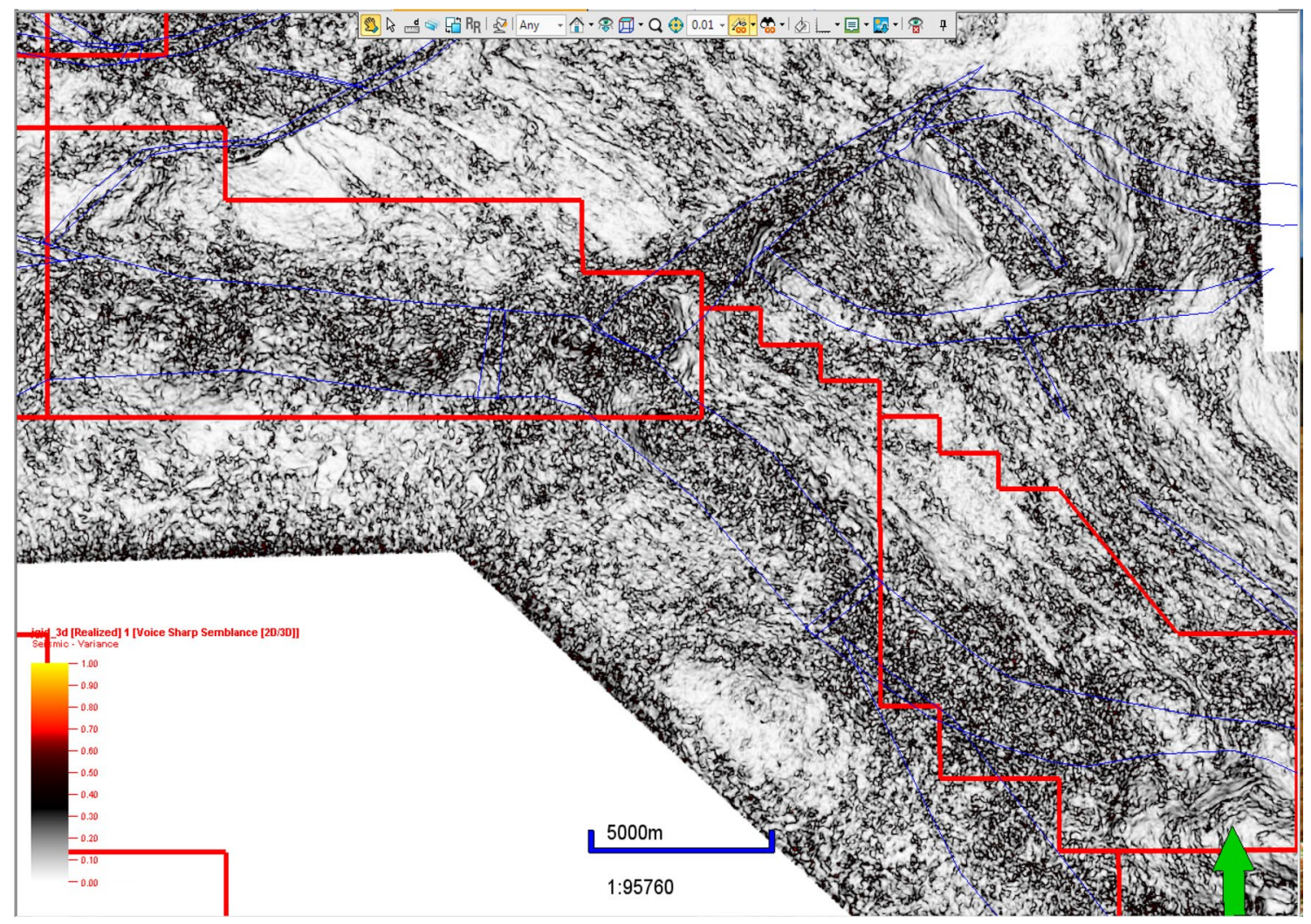

Fig. 11 Semblance slice at $2050 \mathrm{~ms}$ over JG and JD fields showing the major Jurassic fault trends. Green arrow refers to the north direction 




Fig. 12 Seismic line passing from JD from the north and then the depocenter of the basin till to AES field from the south

preexisting normal faults by right-lateral wrenching. Local convergence in some parts of the basin is attributed to strike-slip movement at restraining fault bends, which causes local development of positive structural areas controlled by folding or reverse faulting. Geologic field data in the north Eastern Desert (Moustafa et al. 1985) indicate post-Late Eocene rejuvenation of the faults by oblique extension (major dip-slip normal components and subordinate right-lateral strike-slip components). This post-Eocene movement can be related to the Late Tertiary period of extension in northern Egypt. Later deformation in northern Egypt during the Oligocene seems to have been caused by ENE-WSW extension and was accompanied by the extrusion of basalts. This extension rejuvenated the old ENE- to E-W-oriented faults as normal or diagonal-slip faults and, in addition, formed NNW-SSE-oriented normal faults parallel to the Gulf of Suez trend. These sets (ENE to E-W and NW-SSE) controlled the deposition of the Miocene rocks in the basin. The three rhomb-shaped sub-basins of the Abu Gharadig basin are "right stepped" and indicate that they were perhaps formed as pull-apart (rhomb) grabens by right-lateral oblique-slip movements on three ENE- to E-Woriented, preexisting right-stepped, en-echelon normal faults and these part will be covered by separate chapter titled by structural evolution of JG and JD fields.

\section{Seismic data interpretation}

The synthetic seismograms were carried out using two key wells Sheba 42-1 and JD4 using NDI (SHELL property package) as follows:

The formation tops of interest were tied to the seismic data, and the seismic interpretation was carried out on the NEAG 3D 2005 data Prestack Depth Migration (PSDM) using NDI software (Fig. 5). The interpretation was done on the final migrated data processed with an updated velocity

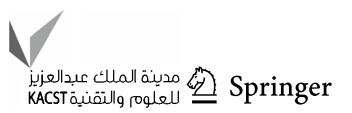




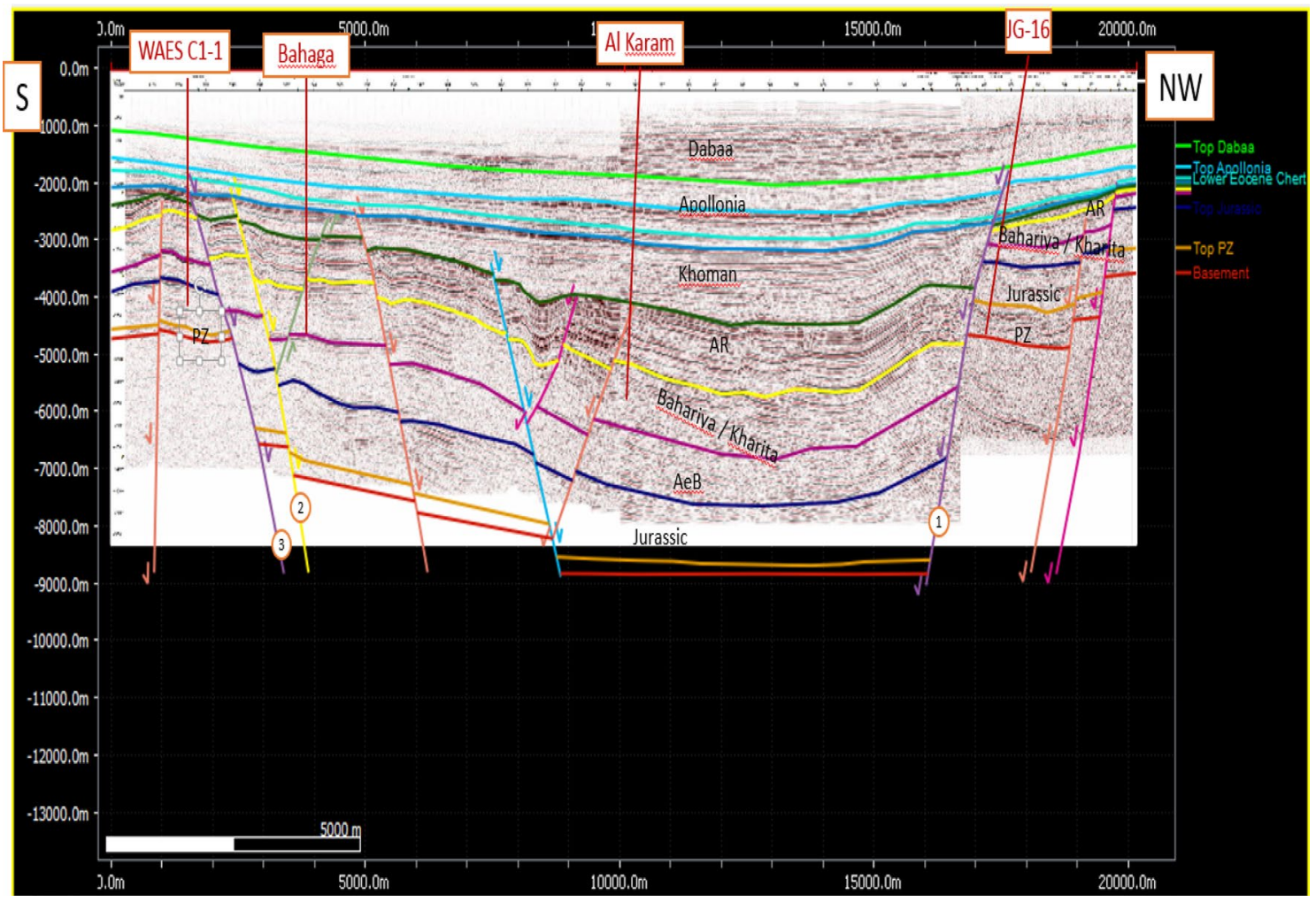

Fig. 13 Seismic line passing from JG from the north and then the depocenter of the basin till to AES field from the south

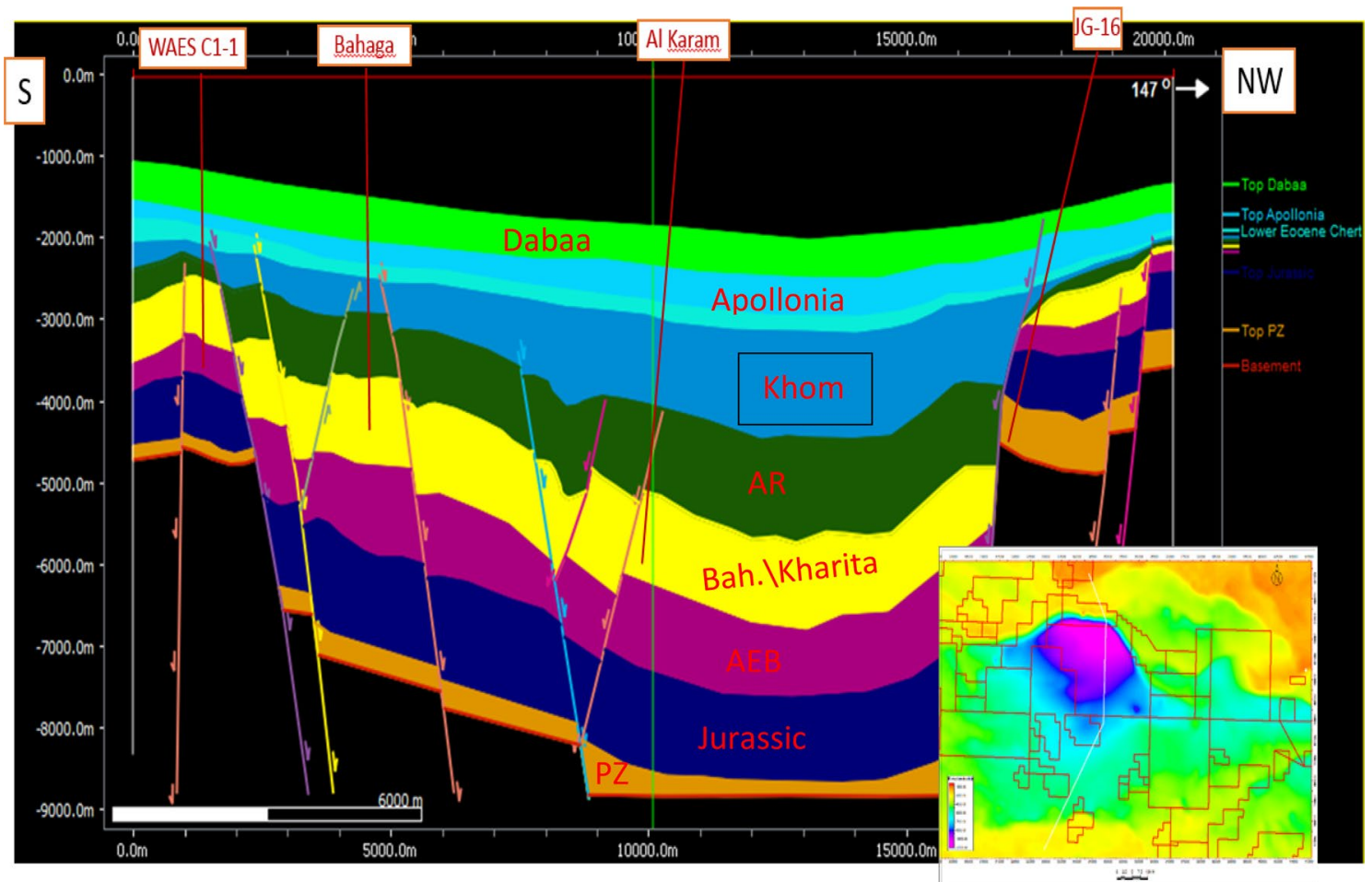

Fig. 14 Geological cross section for AG basin from JG terrace 


\section{Geological X-section for AG Basin including BTE structure}

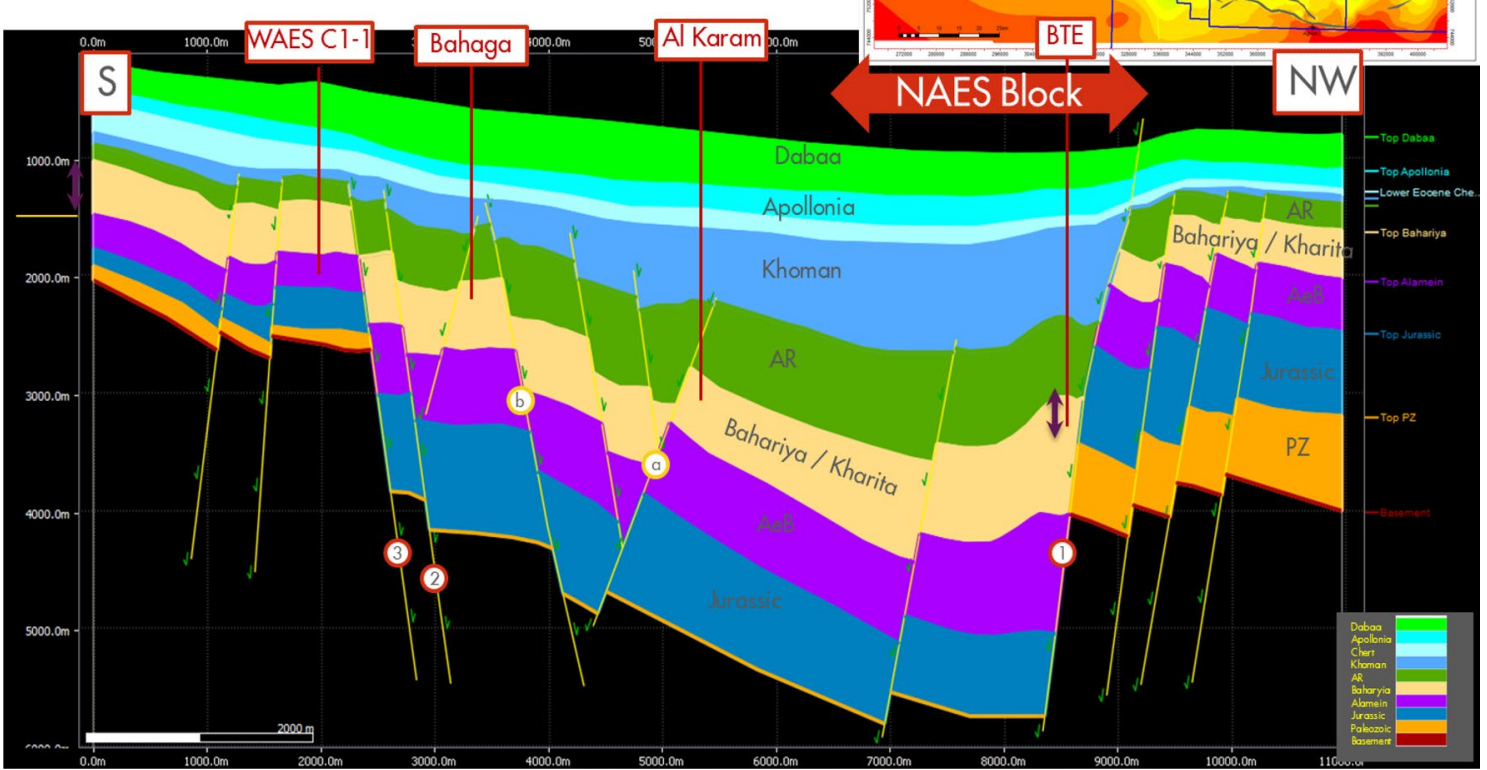

Fig. 15 Geological cross section for AG basin from JD terrace

model. This dataset was fully interpreted over the JG and JD fields. Time-converted full-stack data were used for interpretation. Masajid is the only Jurassic horizon that could be mapped regionally. Top Masajid is an unconformity surface between Jurassic and Cretaceous. The horizon interpretation carried out every $4 \times 4$ lines and cross lines. The main fault interpretation carried out every ten lines. The next figures show that JD block is deeper than JG block and separated by major Jurassic fault (Figs. 6, 7, 8, 9).

The previous seismic line shows a typical Jurassic fault in trend A-B on the depth map for Masajid and the Jurassic faults in the northwestern desert characterized by

1. Syndepositional faults.

2. SW-NE-oriented faults mainly.

3. Growth faults at the Jurassic-Late Cretaceous time.
The Semblance cube over the survey has been carried out, and it shows clearly the major faults and some minor faults, especially the faults that are away from the main bounding faults due to the fault shadow effect.

The next figure shows schematic map showing the Cretaceous and Jurassic fault system over JG and JD fields (Figs. 10, 11).

\section{Restoration}

Cross-sectional restoration is a potentially powerful tool for structural analysis. The objective of the restoration process is to unfold and unfault actual geologic data starting with the present state of deformation. The total deformation of a sequence can be described as the sum of deformation due to folding, faulting and compaction; therefore, all effects should be considered to restore profiles correctly (Novoa et al. 2000). The method used in this study for restoration 


\section{U. Eocene Apollonia limestone penplaination}
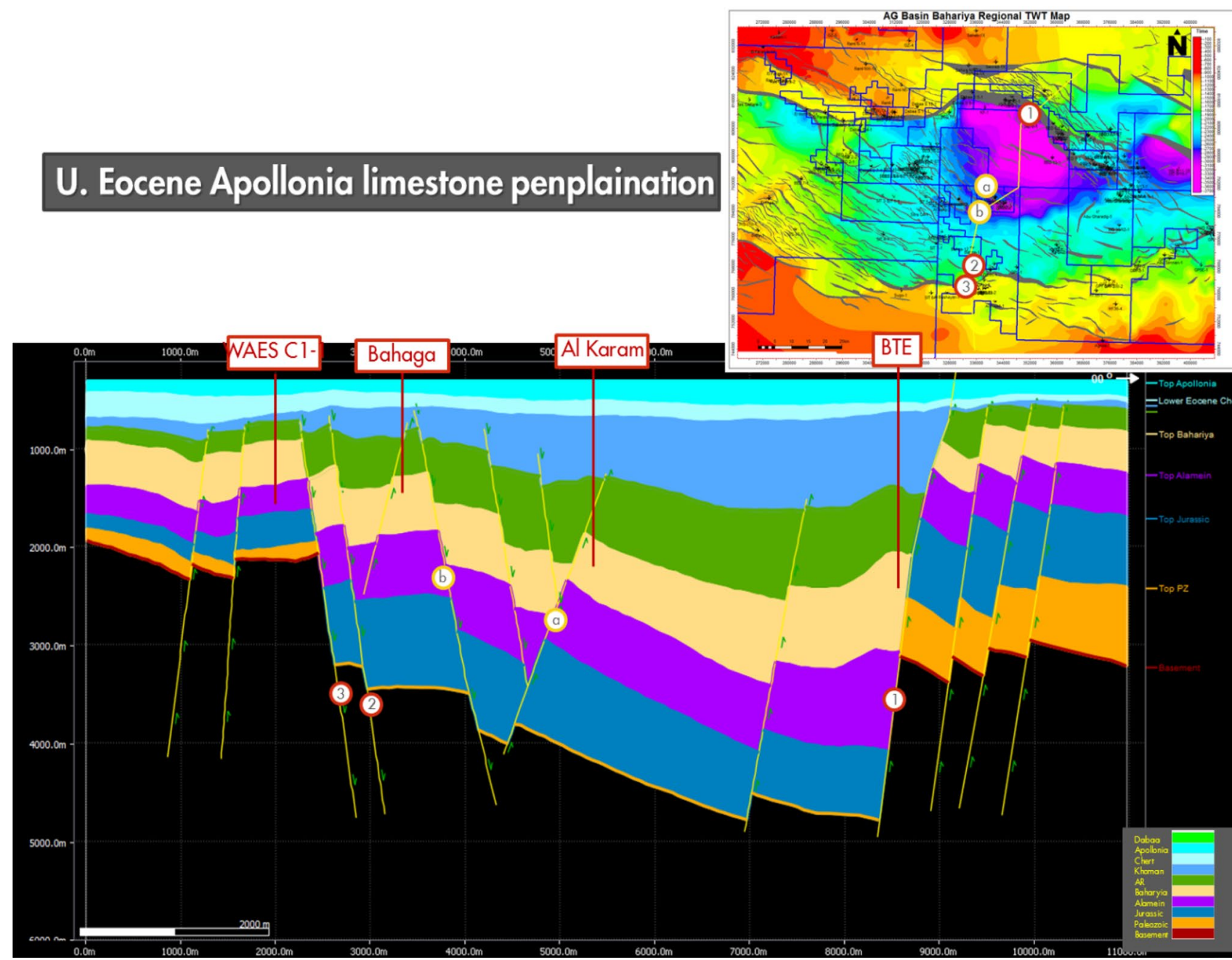

BTE
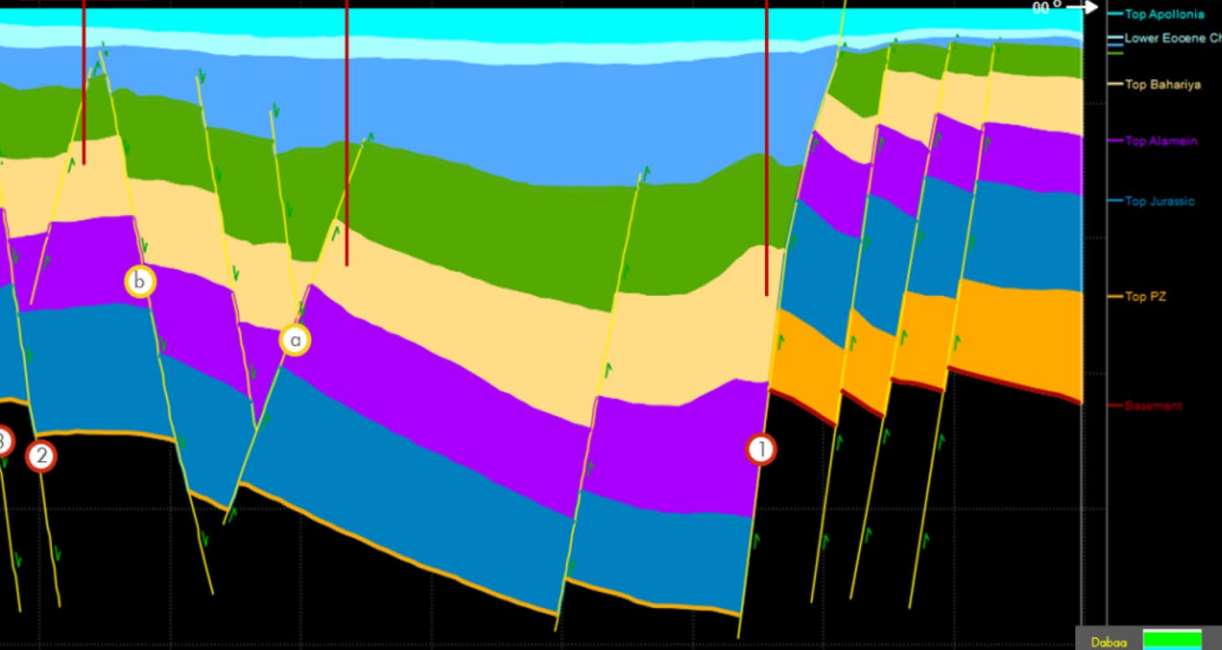

Fig. 16 U. Eocene Apollonia limestone penplaination (oil expulsion)

combines structural and back-stripping techniques and consists of three major steps.

The first step consists of restoring faults and folds (using the proper algorithm available in Midland Valley's Move software). Conceptually, a correct restoration moves points from their present position $(X, Y)$ to the position that they occupied before folding and/or faulting $(X 0, Y 0$ (Novoa et al. 2000). Even though natural deformation is substantially more complex than any algorithm available, the choice of an appropriate algorithm is a key factor during restoration since different algorithms frequently produce noticeably different restored geometries. Two regional seismic lines have been used for restoration: the first one coming from JD block from the north and the second one coming from JG to the north, and both of them are running to the south where Abu Gharadig basin depocenter and till to Alam Al Shaweesh field on the other side of the basin. Then, nine horizons and the faults on the seismic lines have been interpreted and the filling polygons between the horizons and the restoration job has been started. The idea is to compare between the two seismic lines at the time of the oil expulsion from the main source rock Abu Roash F from the depocenter of Abu Gharadig basin which is about upper Eocene-Miocene at the time of Apollonia sedimentation Abu El Ata and Mansour (1991), and these will help us to figure out why Jurassic reservoirs are producing in JG and not producing in JD (Figs. 12, 13, 14). 


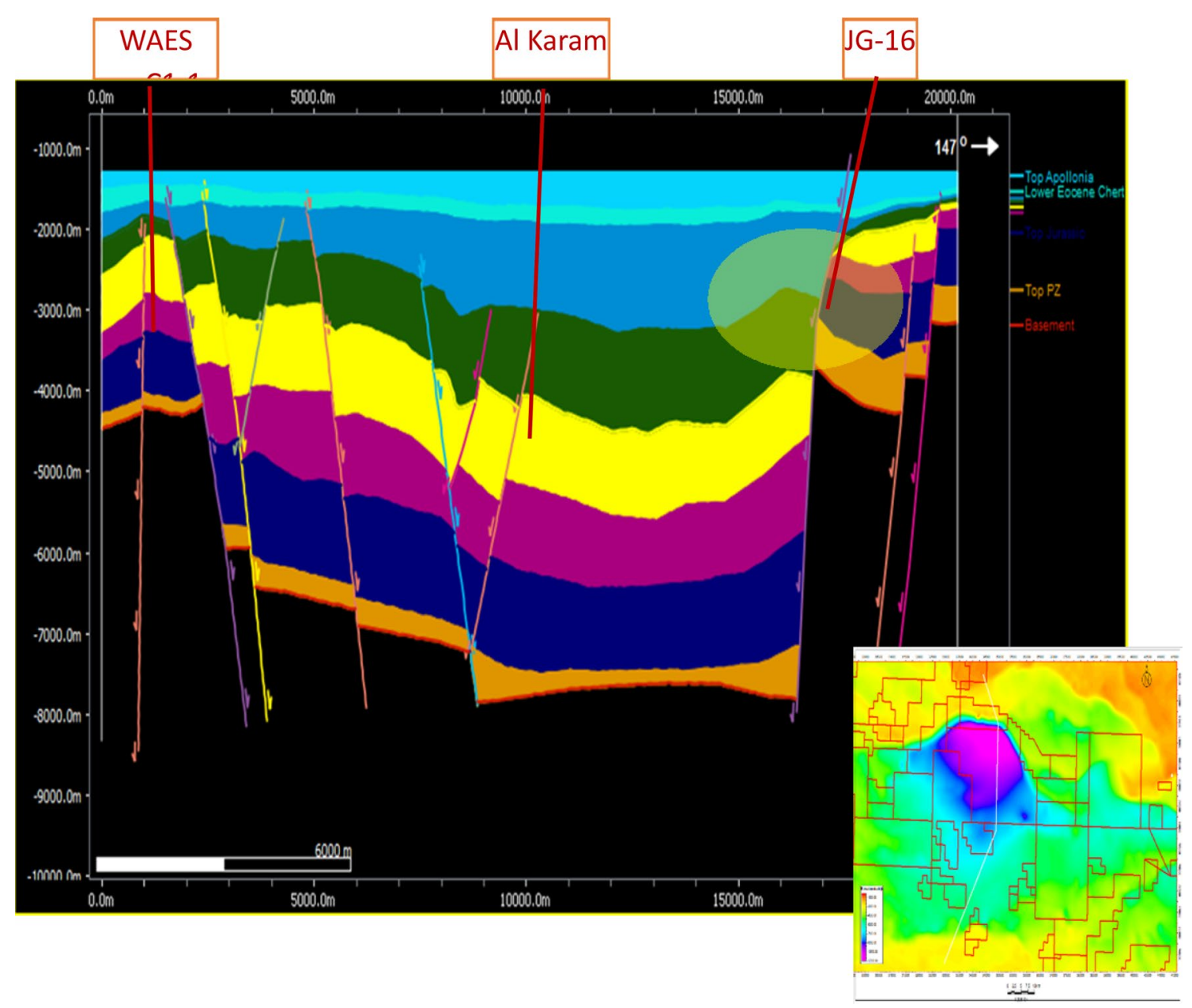

Fig. 17 U. Eocene Apollonia limestone penplaination (oil expulsion). Note that our reservoir section juxtaposition as shown in the upper section Jurassic juxtaposed Abu Roash section (mainly shale and limestone), especially at the lower part (the main reservoir)

The structure of the JG field is an elongated E-W fault dip closure bounded to the south by the Cretaceous Abu Gharadig basin-bounding fault. It is bisected by a series of smaller ENE-WSW and NW-SE trending. The JD structure consists of an elongated NE-SW-trending fault/dip closure mapped at the Jurassic Masajid level. To the SW, the JD closure is bounded by the Abu Gharadig basin-bounding faults. This fault system consists of fault throw transfers and a complex of relay ramps and hard fault linkages all in an area with poor seismic data quality. Toward the SE, the main AG fault terminates and the main part of the fault throw is transferred to the southern fault and a relay ramp is developed in between the two faults which are well developed at the Base Khoman level in the basin. Another fault is developed $\mathrm{E}$ of the main AG fault, and this fault also takes over part of the throw of the main AG fault. This fault is linked to the main AG fault by a relay ramp at Alamein level and by a hardlinked fault at the Masajid level (Figs. 15, 16).

Note that our reservoir section juxtaposition as shown in the upper section Jurassic juxtaposed Bahariya-Kharita (mainly sand stone) section, especially at the lower part (the main reservoir), will lead to the hydro carbon escaping to shallower section to accumulate (currently JD producing only from Apollonia) (Fig. 17).

The previous figures show the steps of the restoration; especially at the time of sedimentation of Apollonia (time of 


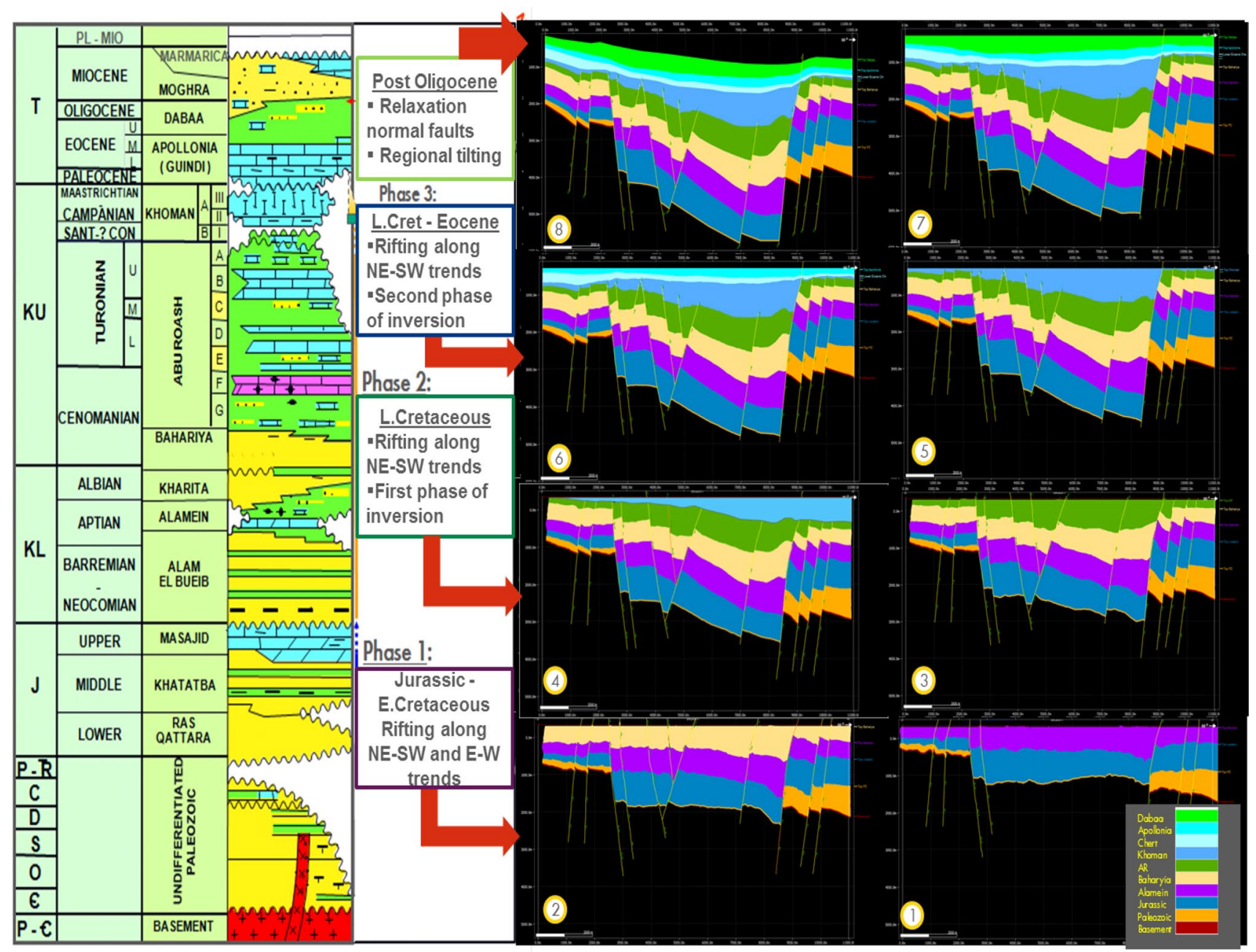

Fig. 18 Summarized restored cross sections from Jurassic up to day

hydrocarbon expulsion), these cross sections show that the juxtaposition at that time in JD area was Bahariya-Kharita (Sandstone mainly) against the Jurassic reservoirs and it means the hydrocarbon will leak to shallower level.

And for JG the juxtaposition at that time in JG area was AR-Khoman (shale, limestone and chalk) against the Jurassic reservoirs as a result of that the hydrocarbon was preserved at the Jurassic Safa reservoirs (Figs. 18, 19).

\section{Fault juxtaposition}

Juxtaposition diagram has been done along the main bounding fault of AG basin from BED2 till to Sheiba field to show the reservoir stratigraphy of both the hanging wall and footwall locations superimposed on the fault plane (Allan diagrams) (Allan 1989). In this case of JG and JD fields (Figs. 20, 21), the juxtaposition diagram shows the following: 


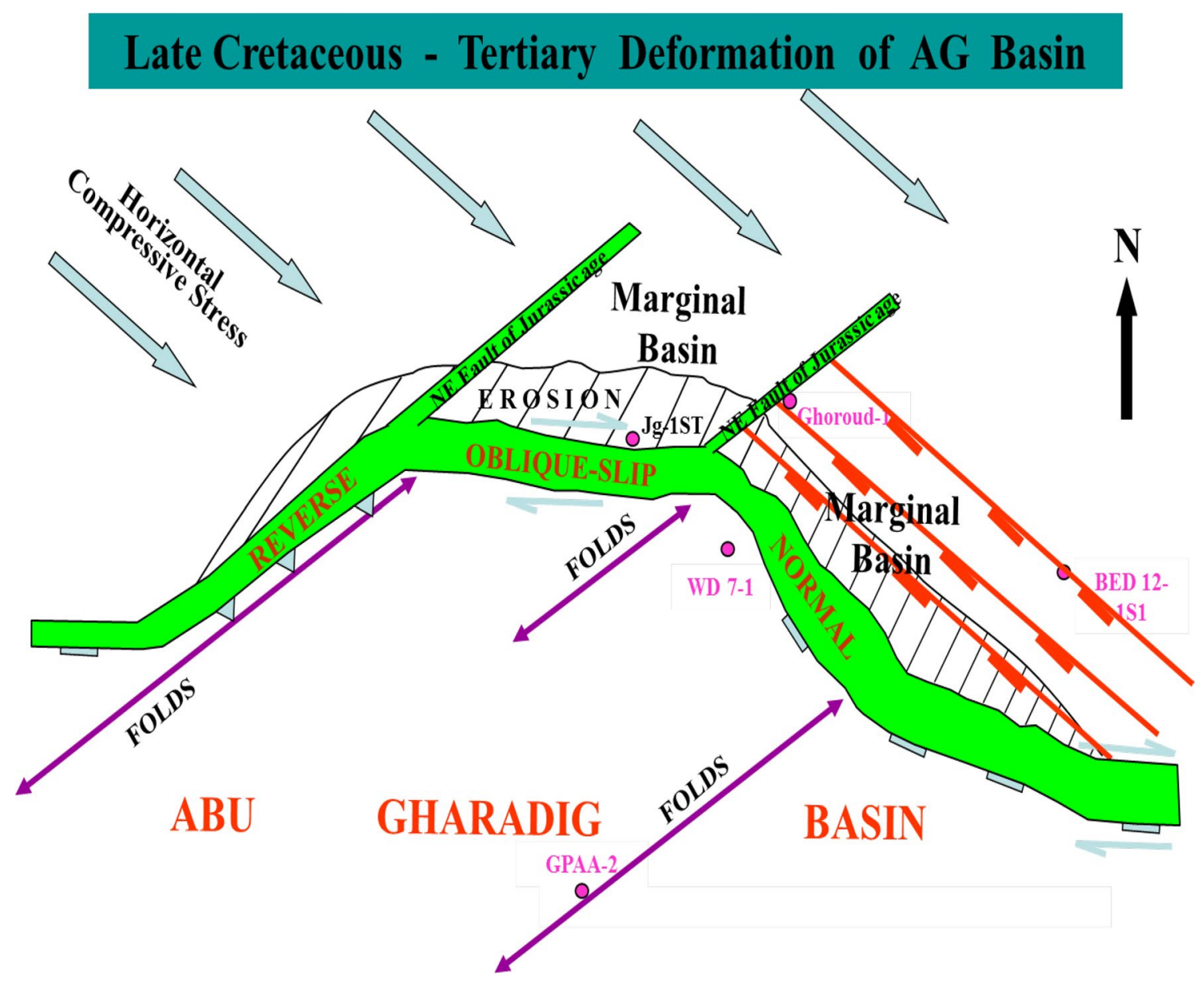

Fig. 19 The Late Cretaceous-Tertiary Deformation of Abu Gharadig basin and it is matches with semblance according to the fault pattern and distribution

1. JG shows largest separation between FW Masajid and HW Abu Roash F member.

2. Juxtaposition of Abu Roash F member and Masajid flip East of JD well and no chance of Abu Roash F member charging Masajid.

3. Khoman chalk HW juxtaposed Jurassic reservoir FW on JG.

4. Bahariya-Kharita (sandstone mainly) juxtaposed Jurassic reservoir FW on JD.

\section{Conclusion}

The main oil expulsion in Abu Gharadig basin was happened at the time of Apollonia age (Paleocene and Lower Eocene) the main reservoirs in JG and JD field Lower Safa and upper Safa (Jurassic), and there are an oil-bearing reservoir in JG field and a water-bearing reservoir in JD. The restoration exercise proves that in $\mathrm{JG}$ the trap was formed and ready to receive the hydrocarbon and the juxtaposition was Jurassic against Abu Roash (shale and limestone) and 


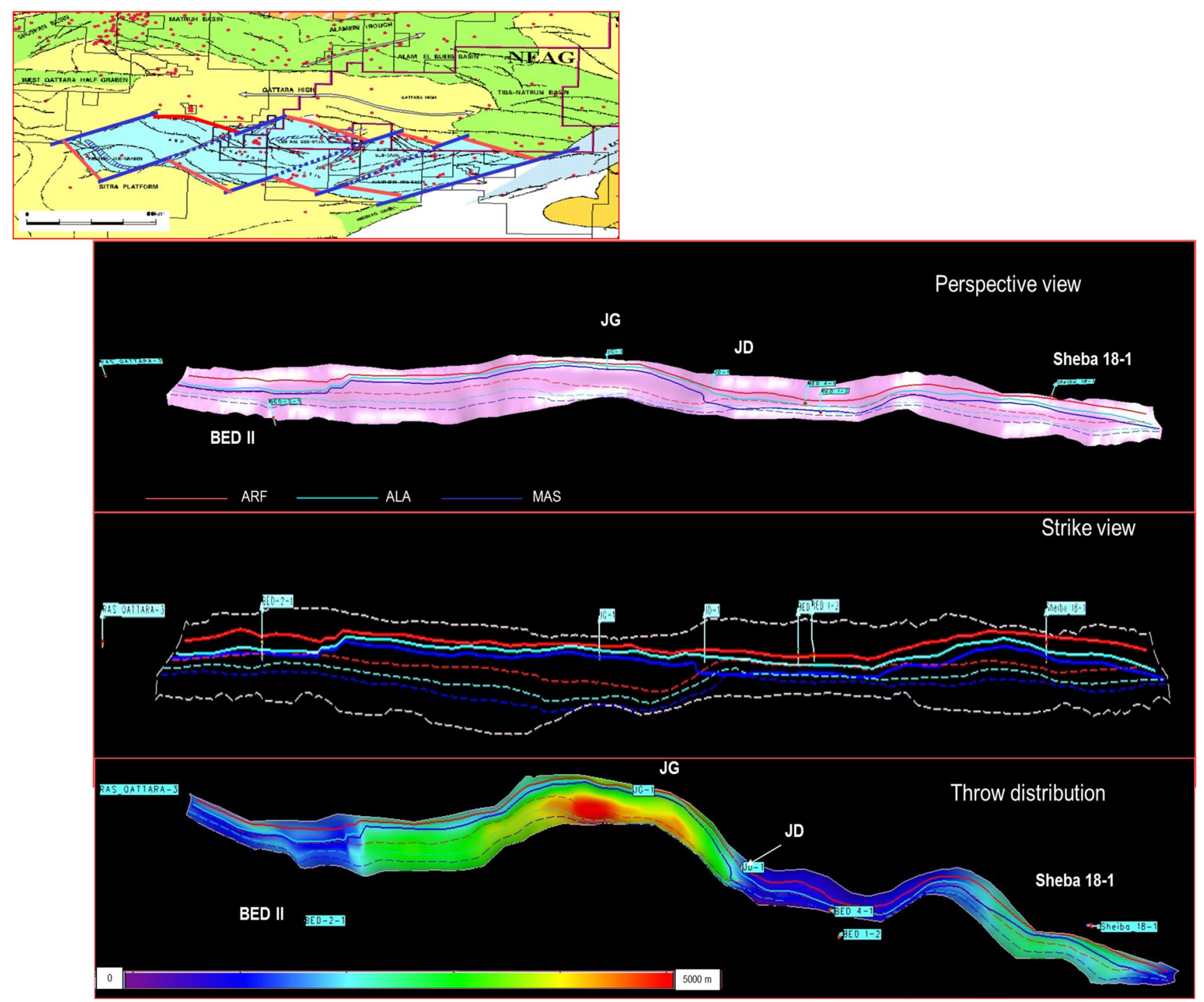

Fig. 20 Juxtaposition diagram on the main AG fault. The lines on the faults represent the lines of intersection of a horizon with the fault surface. Solid lines are footwall intersection, whereas dashed lines are the hanging wall intersections; hence, for a given horizon, dashed

Khoman (chalk) partially so the hydrocarbon was trapped and saved till today because the current juxtaposition is Jurassic against Khoman. In the opposite side, in JD the trap was formed and ready to receive the hydrocarbon and the juxtaposition was Jurassic against Bahariya-Kharita section (sandstone mainly) and it is a bad condition to keep the hydrocarbon inside the tarp so the hydrocarbon was reached to shallower section (Apollonia gas reservoir). The juxtaposition exercise proves that Abu Roash F member and Masajid flip East of JD well and no chance of Abu lines will be deeper than solid lines. Red lines are Abu Roash F member, cyan lines are Alamein, and dark blue lines are Masajid. The variation of a line's elevation on the fault surface is related to the geometry of the hanging or foot walls

Roash F member charging Masajid and the current-day juxtaposition for JG is that Khoman chalk HW juxtaposed Jurassic reservoir FW and Bahariya-Kharita (sandstone mainly) juxtaposed Jurassic reservoir FW on JD. This study recommended the following items:

1. Apply $2 \mathrm{D}$ and $3 \mathrm{D}$ restoration exercises on any prospect, especially they are located on the main bounding faults and the major faults.

2. Build a fault juxtaposition diagram (Allan diagram). 


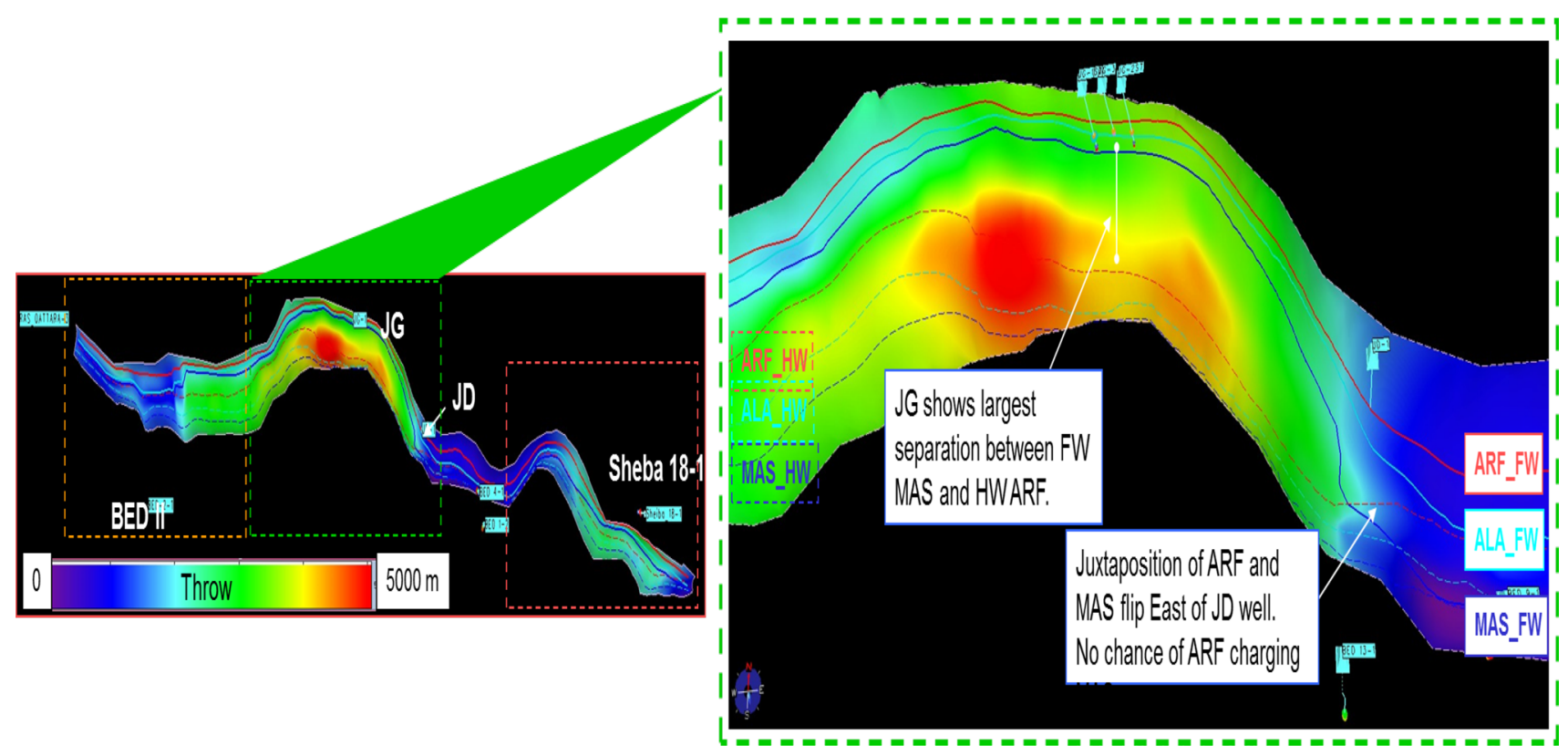

Fig. 21 Main north-bounding fault juxtaposition evaluation

Acknowledgements The authors thank the Egyptian General Petroleum Corporation (EGPC) for releasing the data of this study. Also deep thanks to Tarek Kamel, Shell Egypt, for advice during writing this manuscript.

Open Access This article is distributed under the terms of the Creative Commons Attribution 4.0 International License (http://creativeco mmons.org/licenses/by/4.0/), which permits unrestricted use, distribution, and reproduction in any medium, provided you give appropriate credit to the original author(s) and the source, provide a link to the Creative Commons license, and indicate if changes were made.

\section{References}

Abdelmalek K, Zeidan S (1994) Cased-hole formation pressure testera practical application for better understanding of hydrocarbon migration and entrapment mechanism in greater Bed-3 area, Western Desert. In: Proceedings of the 12th EGPC exploration and production conference. Cairo, Egypt, pp 263-276

Abu El Ata ASA, Mansour MA (1991) The effect of paleotectonics on the migration, accumulation and entrapment of hydrocarbons in the Abu Gharadig basin, Western Desert, Egypt. In: 29th Annual meeting of Egyptian geological survey, Egyptian Geological Survey, Cairo, pp 9-14

Allan US (1989) Model for hydrocarbon migration and entrapment within faulted structures. AAPG Bull 73(7):803-811
Biju-Duval B, Letouzey J, Montadert L (1979) Variety of margins and deep basins in the Mediterranean. Am Assoc Pet Geol Mem 29:293-317

Guiraud R, Bosworth W (1997) Senonian basin inversion and rejuvenation of rifting in Africa and Arabia: synthesis and implications to plate-scale tectonics. Tectonophysics 282(1-4):39-82

Lotfy AIBHI (1989) Modes of structural evolution of Abu Gharadig Basin, Western desert of Egypt as deduced from seismic data. J Afr Earth Sci Middle East 09:273-287

Meshref WM, Beleity AEH, Hammouda H, Kamel M (1988) Tectonic evolution of Abu Gharadig basin. In: AAPG Bull; United States, vol 72, No. CONF-8809346

Moustafa Adel, Yehia A, Abdel Tawab S (1985) Structural setting of the area east of Cairo, Maadi, and Helwan. Sci Res Ser 5:40-64

Novoa E, Suppe J, Shaw JH (2000) Inclined-shear restoration of growth folds, vol 84

Orwig ER (1982) Tectonic framework of northern Egypt and the Eastern Mediterranean region

Schlumberger (1984) In: Well evaluation conference. Egypt, pp 64

Schlumberger (1995) In: Well evaluation conference. Egypt, pp 87

Schürmann HME (1974) The Pre-Cambrian in North Africa. Brill Archive

Smith AG (1971) Continental drift. In: Gass IG, Smith PJ, Wilson RCL (eds) Understanding the Earth. Artemis Press, Sussex, pp 212-231

Publisher's Note Springer Nature remains neutral with regard to jurisdictional claims in published maps and institutional affiliations. 